\title{
Disrupted Democracy in Ukraine? Protest, Performance and Contention in the Verkhovna Rada
}

\author{
SARAH WHITMORE
}

Abstract

Protest performances inside parliament articulated claims to uphold democracy that contributed to the maintenance of pluralism in Ukraine during attempted authoritarian consolidation. Simultaneously, such protests were para-institutional instruments in the ongoing power struggle engendered by a patronal system where formal institutions and norms weakly constrain actors. A diverse repertoire of protest, including rostrum-blocking, visual protest, withdrawal, auditory disruption, somatic protest and the spectacle, was used frequently and was adapted in response to changes in the political opportunity structure. Innovations to the repertoire adapted performances from social movements.

In recent years, violent altercations and theatrical protests in Ukraine's parliament involving tens of deputies have attracted attentive publics to a wide range of issues from language use, imprisoned opposition politicians and deputies' multiple voting violations, but such spectacular performances belie hundreds of routinised deputies' protests on procedural and policy matters. Both raise important questions about Ukraine's political system and democratic practice ${ }^{1}$ more widely. How should we understand such protests, which are conducted by elected representatives that are already privileged in the system of power and have a range of formal legislative tools for protest at their disposal (Spary 2013), but choose instead to disrupt parliamentary proceedings? Why were such modes of behaviour so prevalent in Ukraine? What do the adaptation of distinctive types of protest reveal about the political system? Could such protests actually signify the vibrancy of democratic practice in Ukraine?

\section{Conceptualising Parliamentary Disruption}

The extant literature on the Verkhovna Rada offers limited orientation on such questions. It has tended to focus on formal institutional development (e.g. Wise and Brown 1996; Whitmore 2004; Khmelko and Beers, 2011) with an emphasis on decision-making (e.g. Herron 2002; Whitmore 2004; Chaisty and Chernykh 2015), though this is often not the main function of a modern legislature (Packenham, 1990). Scholarly research on informal practices in Ukraine has tended to focus on covert activities related to neopatrimonial aspects of the political system more

\footnotetext{
${ }^{1}$ Democratic practice here connotes the activities that constitute democracy, 'performed by people, with aims, on stages' (Parkinson 2012, p.23-4).
} 
broadly (e.g. Zimmer 2006; D’Aneiri 2007; Pleines 2016) and attention to overt, public parliamentary rule breaking and protest was, at best, peripheral (Whitmore 2004: 178-9) before Shukan. Shukan's (2013) ethnographic study of the 2006-12 period was the first scholarly attempt to explain patterns of parliamentary disruption in Ukraine. Despite its empirical richness, here parliamentary disruption was defined as 'specific forms of violence that the Ukrainian parliament uses regularly' (Shukan 2013, p.440) that included blocking the central speaker's rostrum and breaking equipment. This conceptualisation is excessively narrow in conceiving of visual and auditory disruptions to parliamentary proceedings as merely accompaniments to large-scale protests and overlooks somatic protests. Such forms of disruptions were sometimes discrete from large-scale protests, with different aims and meanings that warrant investigation. Thus, it is necessary to utilise a broader definition of disruption to capture the breadth of the repertoire of disruption re-produced in the Verkhovna Rada and the variety of functions and meanings that can be attached to various disruptive performances. This study will, first of all, seek to map this repertoire before decoding its meanings. The task will be aided by drawing upon the recent theoretical and comparative literature on parliamentary disruption.

There has been a recent upsurge of scholarly interest in parliamentary disruption, which has sought to locate disruptive actions as part of, rather than against, democratic practice (Rai 2013, p. 385). Spary (2013) identifies distinct theoretical approaches underpinning the literature on parliamentary protest which affect the interpretation of such actions in terms of their intended audience, causes, reception and justification. The narrowest, 'conflict' perspective evaluates legislatures by their ability to contain conflict, where disruption is seen as caused by opposition's desires to obstruct government legislation or as the staging of dissent as part of the broader political spectacle (Spary, 2013, p.397-8). In this vein, Gandrud (2016) explains legislative violence as shaped by credible commitment problems in the wider political environment, disproportionality of electoral outcomes and institutional instability in new democracies. Such approaches then emphasize how legislative protest reflects, constitutes and symbolises narratives of broader political conflict. However, this only gets us so far. Not all protest is enacted by opposition politicians and such an approach privileges order and so delegitimises protest, some of which may be justified if the legitimacy of government actions are under question (Spary 2013, p.398). Other scholars have sought to contest the notion that disruption is inherently illegitimate and undemocratic, and to consider the ways in which such performances can offer opportunities for marginalised groups to challenge existing power structures (Rai 2013, Johnson 2013). Spary (2013, p.392) thus advocates a broad definition of legislative protest as 'disruptive behaviour of elected representatives within legislative settings' that encompass 'a wide variety of actions that elected representatives perform in order to bring attention to a point they wish to 
make during chamber debates and other parliamentary proceedings'. This definition would encompass the range of protests prevalent in the Verkhovna Rada including rostrum blocking, withdrawal, visual, auditory and somatic disturbances, providing a suitable conceptual boundary for the empirical categorisation of the Rada's performances and repertoires of protest. To take this further, the work on contentious politics is insightful.

\section{Performance and Contention}

Tilly and Tarrow's notions of political claim-making as performance and repertoires of contention $(2007,2008)$ apply beyond social movements and so can be useful for conceptualising protest actions enacted inside a legislature such as the Verkhovna Rada. Here the patronal, winner-takes-all political system can, at certain junctures, lead the parliamentary opposition to behave like social movements in certain respects, such as using an array of disruptive public performances to make claims on the regime and engaging in repeated displays of worthiness and unity (Tilly and Tarrow, 2007, p.8). Such forms of contention were distinct from social movements as they were performed by constituted political actors with access to stable resources (money, organisation, access to the state) (Tarrow 1998, p.5-6) and could claim legitimacy through popular election. These resource and legitimacy endowments made the risks and costs of transgressive protest lower than for participants of social movements, so such similarities are naturally partial, although deputies brought experience of street protests into parliament and these influenced innovations to the protest repertoire.

The idea of contentious politics is also useful for understanding parliamentary disruption in a broader sense by focusing on the performance when one actor makes a claim on another, staged for nearby or distant audiences. Although many performances are modular and can be adapted and adopted across a wide range of political contexts and actors (e.g. the mass demonstration, the sit-in) the precise nature of adaptation (or non-adaptation) depends on local context and the political opportunity structure offered by particular regimes (Tilly 2008, Tilly and Tarrow 2007, pp.12-14) and are subject to continual innovation. Such performances 'clump into repertoires of claim-making routines that apply to the same claimant-object pairs' (Tilly 2008, p.14) giving the claimant a range of tools upon which to draw to make a collective claim. The notion of repertoire draws attention to the 'clustered, learned and improvisational character' of claim-making interactions (Tilly, 2008, p.14). Such repertoires are shaped by features of the political opportunity structure (Tilly and Tarrow 2007, p.49).

The political opportunity structure 'refers to the features of regimes and institutions ... that facilitate or inhibit a political actor's collective action and to changes in those features' (Tilly and Tarrow 2007, p.49). Tilly and Tarrow (2007, p.55-7) single out 'the extent (or lack) of democracy' and government capacity as most significant in 
shaping political contention, pointing to the properties of the regime such as the number of independent power centres, the (in)stability of political alignments, the availability of influential allies for challengers and the extent of repression of collective claim-making performances. The political regime constrains the prevailing mix of contentious performances over time by prescribing, tolerating and forbidding different sorts of performances, which may then be contained, or transgressed by claim-makers (Tilly and Tarrow 2007, pp.48-64). This study aims to identify and categorise the performances and repertoires of disruptive protest in the contemporary Verkhovna Rada, to explore their meanings and significance for the political system, and to account for the adaptation and innovation of the protest repertoire over time, including insights into about extent of political change after the Revolution of Dignity.

\section{Data Collection}

The main data collection period for this project was 2012-2016, permitting a comparison of protest under presidents Yanukovych and Poroshenko, but the study extended backwards to 1990 (see Whitmore 2018) and drew on an extensive personal archive. Observation of plenary sessions comprised an important form of data collection. I benefitted from the live online broadcasts and videos of plenary sessions on the RADA channel, which entail a loss in control over what is observed, though offered compensation in accessibility and therefore extensiveness. Such observations were crucial because much of the routine protest is ignored by the print media, or only covered incidentally, rendering claims about the frequency of various types of protest impressionistic. Additionally, a wide range of Ukrainian media 2012-16 and think-tank reports were closely scrutinised. During 2012-16, 14 in-depth interviews with local experts were conducted in Kyiv. It also seemed important to consult parliamentarians themselves about these practices, despite the problematic nature of asking individual participants in controversial group behaviours to retrospectively assign motives and meaning to their actions. Shukan (2013, p.443) noted the defensive attitude of most deputies interviewed in her study and this was replicated among the 10 (of 34 approached) opposition and non-aligned deputies were interviewed for this study in $2013 .{ }^{2}$ All 20 'majority' deputies (from the Party of Regions and Communists) approached to participate refused. Deputies often found the topic itself provocative, with two deputies even walking out of the interview. While it remains important to ask participants in protests about their experiences, these can provide only a partial account of the meanings of

\footnotetext{
${ }^{2}$ Deputy interviews were conducted in the Verkhovna Rada by Svitlana Matvienko (Agency for Legislative Initiatives), May-June.
} 
parliamentary disruption. Deputies by their nature are enmeshed in the ongoing political struggle and embedded within the institutional norms, practices, symbols and rituals of parliament and the power relations these constitute and seek to mystify. As Kertzer (1988, p.184) cautions, our own rituals are most difficult to see. Therefore, deputy interviews at a particular time can help illuminate (some of) their perceptions on protest actions at that time, but this can only be a jumping off point for analysis. ${ }^{3}$

Drawing on the extant literature, I have established a conception of parliamentary disruption that encompasses the wide spectrum of activity in the Verkhovna Rada which can then be inductively categorised into performances and repertoires of protest. Relating such actions to broader debates about deliberative democracy can help us understand the ways in which various types of protest are performed in Ukraine, to separate analytically those protests with concrete (material) goals from those that sought to offer a symbolic challenge to regime legitimacy or primarily to mobilise one's electorate, even though Ukraine is best understood as a hybrid regime throughout the period. This paper will demonstrate that the Rada's protest repertoire comprised six modes but was subject to significant innovation over time, and that this occurred in response to the changing political opportunity structure: Under President Yanukovych, the Ukrainian parliamentary opposition came to act in many ways like a social movement because the political opportunity structure excluded them from the main formal institutional channels and patronal networks of influence, and protest was used to gain concrete advantages in the ongoing power struggle and to advance symbolic claims about the illegitimacy of the current regime. Under President Poroshenko, as levels of political contention lessened in the context of war and the Rada had a greater role in decision-making, protest was more marginal, and to some extent became ritualised and connected with electionneering. To advance these arguments, firstly an overview of Ukraine's parliament in the context of the wider regime dynamic will facilitate the identification of the political opportunity structure for protest activities across time. Secondly, the performances and repertoires of protest will be mapped, considering the performance, motivations, audiences and effects. At the same time, innovations to the protest repertoire will be explained by changes in the political opportunity structure. Thirdly, the (in)effectiveness of sanctions will be addressed. Finally,

\footnotetext{
${ }^{3}$ A series of focus groups were conducted in 2016 to explore citizens' perceptions of the Rada and protests inform this study, but are the subject of a separate paper.
} 
I will offer some discussion about why such practices persist and what this tells us about the Verkhovna Rada, the system of power and democratic practice in Ukraine.

\section{Mapping the Political Opportunity Structure, 2012-16}

To understand why deputies engaged in particular patterns of protest, the evolving political opportunity structure during 2012-16 will be outlined, but first it is argued that ideas of democracy are needed to decode parliamentary performances and the types of claims being made, even if they tell us little about Ukraine's regime type. It is the patronal features of Ukraine's political system - the form of the hierarchical structuring of power and the informal rules of the game that condition this - combined with the specific balance of political forces represented in the parliament, including the alignment of the speaker, that comprise what Tilly and Tarrow (2007) call the political opportunity structure. This, to a large degree, explains the evolution of protest repertoires.

For most of its first 25 years as an independent state, including the period under investigation, Ukraine was not characterised as a functioning democracy (although Freedom House assessed it as 'fully free' during 2005-10, an unprecedented distinction in the (non-Baltic) post-Soviet space (Hale 2016, p.325)). So what grounds are there for framing this paper in terms of democratic practice drawn from conceptions of deliberative democracy, in particular the role of parliament in that type of politics? Political authority in independent Ukraine rested on democratic claims and the notion that the Verkhovna Rada formally embodied the representative branch of power at the national level. This was confirmed in the 1996 Constitution. So formally the Verkhovna Rada is a democratic institution that acts as the stage for the performance of democratic roles such as the enactment of grand national rituals and symbolic statements of national identity as well as sites for deliberation and decision making, including making and challenging claims to represent; communicating decisions to society, and making claims to public office (Parkinson 2015, pp.17, 37-9). Thus, at least at the formal level, when examining parliamentary practices, appeals to conceptions of democracy are meaningful. Furthermore, and crucial for our purposes, in the Rada, parliamentary disruptions were usually accompanied by appeals to democratic norms. Although these may be seen as instrumental, democratic ideas do constitute an important part of the discursive framework for parliamentary disruption in Ukraine and so are necessary to develop understandings of its meanings. Nevertheless, due to the informal nature of Ukrainian politics, they are far from sufficient.

\section{Patronal politics}


Although Ukraine has made important steps towards democracy in the post-Soviet period, most notably in pluralism and competitiveness, scholars tend to agree that it is best understood as a hybrid regime, drawing particular attention to the existence of formal democratic institutions (the constitution with separation of powers, competitive elections, media and party pluralism etc) that are suffused by neopatrimonial relations (rent-seeking, clientelism, patronage etc) (see Zimmer 2006; also Hale 2015; Levitsky and Way 2010; Matsiyevsky 2018). In terms of mapping the political opportunity structure for parliamentary disruption provided by Ukraine's political system, Hale's (2015) notion of patronal politics offers insightful orientation at the regime level due to its emphasis on informal (patronal) politics and its dynamic understanding of regime equilibria, which can help explain Ukraine's institutional fluctuations and elite reconfigurations since independence.

Patronal politics is organised 'primarily around the personalised exchange of concrete rewards and punishment through chains of actual acquaintance' (Hale 2015, p.9) and power tends to be organised around hierarchical networks rooted in local political machines, financial-industrial groups (FIGs) and various branches of the state that are rich in either cash or coercive capacity. Whoever controls these networks controls the country and the most important function of the constitution in patronal systems is to shape elite expectations about who the patronin-chief will be. In such systems, the most important distinction is whether there is a single pyramid uniting these networks or whether they are divided among multiple, usually competing, pyramids. A constitution denoting a single dominant chief executive signals to elites that the president will wield the power to punish and reward, whereas where executive power is divided between a president and a prime-minister, there will be an alternative focal point for elites to access resources and space for third networks.

\section{Patronal politics and elite reconfiguration in Ukraine}

This provides an elegant schema for understanding the dynamic of Ukraine's hybrid regime, which has oscillated between partially-authoritarian and partially-democratic phases without fundamental change of the underlying political relations, which remain patronal. 
Table 1: Patronal politics and regime configuration in Ukraine 1991-2016

\begin{tabular}{lllll}
\hline Year & President & $\begin{array}{l}\text { Constitutional } \\
\text { Arrangement }\end{array}$ & $\begin{array}{l}\text { Configuration of } \\
\text { networks }\end{array}$ & $\begin{array}{l}\text { Freedom House } \\
\text { score }\end{array}$ \\
\hline $\mathbf{1 9 9 1 - 1 9 9 4}$ & Leonid Kravchuk & Divided executive & Multiple pyramid & $3.0-4.0 \mathrm{PF}$ \\
$\mathbf{1 9 9 5 - 2 0 0 4}$ & Leonid Kuchma & Single executive & Single pyramid & $3.5-4.0 \mathrm{PF}$ \\
$\mathbf{2 0 0 5 - 2 0 1 0}$ & Viktor Yushchenko & Divided executive & Multiple pyramid & $2.5 \mathrm{~F}$ \\
$\mathbf{2 0 1 0 - 2 0 1 4}$ & Viktor Yanukovych & Single executive & Single pyramid & $3.0-3.5 \mathrm{PF}$ \\
$\mathbf{2 0 1 4 -}$ & Petro Poroshenko & Divided executive & Multiple pyramid & $3.0 \mathrm{PF}$ \\
\hline
\end{tabular}

Key: $\mathrm{F}=$ Free; $\mathrm{PF}=$ Partly Free. Freedom House scores run 1-7 with lower scores indicating greater freedom. Source: Freedom House (www.freedomhouse.org)

Table 1 summarises these regime dynamics, giving Freedom House scores to denote the extent of system openness, and Hale (2015) gives a compelling account of these oscillations over the period of Ukrainian independence. The period of our focus, 2012-16, comprises distinct hybrid phases: moving towards political closure, rupture and then greater competitiveness.

Following his election in 2010, Viktor Yanukovych moved swiftly (and illegally) to restore the 1996 Ukrainian constitution which designated the president as the single chief executive, with powers to appoint and dismiss the government. This greatly facilitated his moves to rapidly construct a single pyramid uniting the key regional, economic and political networks, and to close the space in the political system for those outside this network. However, Yanukovych's regime ultimately was brought down by authoritarian overreach as some networks associated with the Party of Regions (PRU) lost resources to members of Yanukovych's 'family' and others did not attain the level of influence they desired (Hale, 2015, p.347, Wilson 2014, p.51-3) and overt corruption propelled the population to the Revolution of Dignity in 2013-14. As Yanukovych fled, parliament reverted Ukraine's constitution to the 2006 divided executive variant, that raised the status of parliament in the political system, whereby the origin and survival of the government was dependent on a parliamentary majority. As elites reconfigured during 2014, the new constitutional arrangement incentivised the emergence of competing centres of power around President Poroshenko and Prime Minister Yatseniuk (2014-16), although this dynamic shifted somewhat once Poroshenko secured his close ally Volodymyr Hroisman as prime-minister in April 2016. Naturally, this outline is very schematic, but is useful for foregrounding informal networks in the functioning of Ukraine's political system, in particular the cycling between more democratic (or, rather, pluralist) and 
authoritarian phases, which scholars see as normal hybrid regime dynamics (Hale 2015; Way 2015; Matsiyevsky 2018).

Informal networks straddling FIGs, state bureaucrats and local political machines shaped not just the broader regime trajectory, but also the structure of the party system, the Rada's composition and the nature of interactions within the parliament. To illuminate the meanings and significance of parliamentary disruption, several dimensions need highlighting. Following the logic of patronal politics, FIGs and other elite networks sought to advance their interests through using their economic power to buy political influence, principally through shaping the formation, organisation, media coverage and parliamentary voting of political parties and groups of individual deputies (Matsuszak 2012). The prevalence of 'rule by law' in Ukraine meant power concentrated in the executive decided not only which businesses obtained lucrative government contracts or generous finance, but also which were subject to harassment by various state regulatory bodies, and which politicians were subject to investigation or arrest. ${ }^{4}$ This patronal politics made deputies' immunity from arrest or prosecution an incredibly valuable commodity for entrepreneurs. As a corollary, rent-seeking was often the primary goal of deputies, who often paid several million dollars for their parliamentary seats for this purpose (D'Anieri 2007, p.197; Wilson 2016, p.9) and so required access to the executive. Consequently, opposition to the executive/chief patron(s) under patronal politics is particularly unattractive, as one risks damaging one's business and, particularly under Yanukovych, imprisonment. This helps to account for the strength of attraction of the chief patron and the undesirability of opposition status.

Parliamentary composition under Yanukovych, 2012-14

Such an environment contributes to the ongoing organisational and ideological weakness of parties (see Rybiy 2013) and the conceptual difficulties of defining 'opposition' in this context, where rent-seeking, patronage and, if necessary, coercive resources are deployed by the executive to form and maintain pro-presidential coalitions (see D'Anieri 2007, pp.196-7; Chaisty and Chernykh 2015, p.14) ${ }^{5}$ and to detach deputies temporarily (e.g. for a significant vote) or permanently (to join a coalition) from the opposition. For example, immediately following his

\footnotetext{
${ }^{4}$ For example, Zerkalo Nedeli, $12^{\text {th }}$ November 2012 published a table listing deputies with "obligations" to the Party of Regions and thus subject to 'pressure'.

${ }^{5}$ For example, in 2013 six deputies reported being offered \$3-6m to leave Batkivshchina (Segodnya, $6^{\text {th }}$ June 2013).
} 
election to the presidency, Yanukovych used a combination of formal rule changes and informal methods to destroy the coalition supporting Prime Minister Yulia Tymoshenko. Thereafter, Yanukovych was able to construct a pro-presidential coalition of his Party of Regions (PRU) together with the Communist Party of Ukraine (CPU), the Bloc of Volodymyr Lytvyn and a number of (now) independent deputies, while Tymoshenko's parliamentary faction, Batkivshchina (Fatherland) shrunk from 155 deputies in September 2010 to 106 by February 2011, ${ }^{6}$ which together with Viktor Yushchenko and former Interior Minister Yuriy Lutsenko's Our Ukraine-Self-Defence (NUNS) comprised the parliamentary opposition. The authorities deployed a range of informal means to weaken the opposition, most infamously arresting and later imprisoning Tymoshenko and Lutsenko on corruption and abuse of power charges in 2011.

The arrest of the leaders of the opposition, including Yanukovych's close competitor in the 2010 presidential elections, constituted a significant change in the political opportunity structure. This move broke the existing informal rules of the game whereby losing opponents were not prosecuted, as Yanukovych himself had not been after falsifying the 2004 presidential elections. Tymoshenko's arrest signalled a further step towards aggressive consolidation of a single pyramid of power and triggered increasing contention in society and in parliament. Consequently, the 2012 parliamentary elections swelled the opposition substantially, changing the dynamic of parliament and permitting the consolidation of more distinctive, coherent and evenly weighted competitors: the parliamentary majority and opposition. Now comprising three factions - Batkivshchina (99 deputies), Vitaly Klychko's UDAR (Punch) (42 deputies) and the radical right ${ }^{7}$ Svoboda (Freedom) Party (37 deputies), the opposition had 178 deputies to weigh against 242 in the coalition of PRU (210 deputies) and CPU (32 deputies). As many deputy-entrepreneurs did not attend regularly, and a majority of votes (226 of 450) was required to adopt legislation, this meant that the balance of forces was actually tighter than the bald figures suggest. In the face of Yanukovych's multi-faceted attempts at authoritarian consolidation (see Kudelia 2014), the three opposition factions were often able to overcome their inter-party competition to cooperate successfully on several issues

\footnotetext{
${ }^{6}$ Verkhovna Rada website (http://gska2.rada.gov.ua/pls/site/p fractions) accessed $19^{\text {th }}$ September 2010, $22^{\text {nd }}$ October 2010 and $21^{\text {st }}$ February 2011.

${ }^{7}$ The extent to which Svoboda were indeed radical or conservative is contested. Here Shekhovtsov's (2011) designation is followed.
} 
within and outside parliament. So, as we shall see, under Yanukovych this political opportunity structure facilitated and prompted extensive use as well as innovation of the protest repertoire.

Parliamentary composition after the Revolution of Dignity, 2014-16

Between Yanukovych's exit in February and the October 2014 parliamentary elections, the sudden power vacuum and gravity of the existential threats facing Ukraine had a pacifying effect on the Rada, as elites realigned and looked for political survival during this interregnum. Despite much freer and fairer elections in 2014, some reconfiguration of parties and the incorporation of fresh blood ${ }^{8}$ from civil society, the underlying structure of party formation and campaigning remained shaped by the involvement of big business and informal politics. ${ }^{9}$ Nevertheless, the Revolution of Dignity, annexation of Crimea and outbreak of war in Donbas fundamentally restructured Ukraine's electoral geography and weakly-institutionalised parties. Notably, the new Rada was less polarised as both the Communists and Svoboda failed to get elected, and a shrunken Batkivshchina (19 deputies) was the only party to get re-elected. So there was less contention in the new Rada, but it looked even more personalised, the winners being hastily convened electoral blocs: around the new president (Bloc of Petro Poroshenko (BPP), 146 deputies); prime minister Yatseniuk's People's Front (83 deputies); the rump of the PRU (renamed Opposition Bloc)(40 deputies); and the mayor of L'viv (Samopomich (Self-reliance)(32 deputies)). ${ }^{10}$ There was little evidence of a reduction in the practice of vote-buying in the Rada ${ }^{11}$ and the lines between the parliamentary majority (formally supporting the Prime Minister in the restored 2006 constitution) and opposition were more blurred than ever. For instance, the populist Radical Party of Oleh Liashko (22 deputies), widely believed to be funded by the oligarch Dmytro Firtash, ${ }^{12}$ rapidly left the majority to become President Poroshenko and the governments' most vocal critic, whilst voting together with the president's bloc and acting as a conduit for the Opposition Blocs bills (Ostapchuk, 2016). The majority officially disintegrated in early 2016 as Samopomich and Batkivshchina left. The new majority formed in April 2016 by BPP and National Front behind

\footnotetext{
${ }^{8}$ Only $44 \%$ of deputies were re-elected.

${ }^{9}$ See Matsiyevsky (2018) on the continuities in parliamentary politics post-2014.

${ }^{10}$ Faction sizes given at registration at the start of the convocation. These were subject to changes.

${ }^{11}$ For example, see the account of former Poroshenko Bloc deputy Onyshchenko, Kyiv Post, $9^{\text {th }}$ December 16.

${ }^{12}$ At least initially, see Ukrains 'ka Pravda, $11^{\text {th }}$ October 2017,

https://www.pravda.com.ua/articles/2017/10/11/7157940/, (accessed $2^{\text {nd }}$ July 2018).
} 
Poroshenko's close ally Vasily Hroisman's government lacked a working majority, and often relied on the votes of oligarchic factions Vidrozhdennia (associated with oligarch Ihor Kolomoyskyi), Volya Narodu and the remnants of the PRU. As in the 1990s, situational majorities benefitted the president most of all, as he was able to use informal methods to shepherd through key bills, while undermining the ability of the Rada to fulfil its constitutional role as the counter-balance intended in the restored presidential-parliamentary system. Thus, from mid-2016 Ukraine's political system was informally shifted towards a single executive, although presidential attempts to consolidate a single elite pyramid foundered in the context of war and Western pressure (Matsiyevsky 2017).

The internal political opportunity structure: Applying the Reglament

Questioning the application of the Reglament (parliamentary standing orders) ${ }^{13}$ was one strategy employed by the opposition in the struggle for power, so procedural disputes were a key cause of parliamentary protest. The Reglament, like much legislation in Ukraine, were framed ambiguously, permitting considerable latitude to a speaker, and a presidential coalition, to bend them to their convenience. As elsewhere in a patronal system, this conferred enormous power to the speaker. Here the relationship of the speaker to the president was crucial in affecting the institutional autonomy of the parliament. During 2010-12, speaker Volodymyr Lytvyn tried to present himself as a neutral figure, but proved willing to do Yanukovych's bidding, even where this involved flagrant violations of the Reglament. Speaker Volodymyr Rybak (2012-14) was a long-time associate of Yanukovych and a leader of the PRU, so the Rada leadership was formally as well as informally aligned with the executive. The 2014-16 period was a period of considerable flux in the parliamentary leadership. During FebruaryOctober 2014 in the interregnum between the Revolution of Dignity and fresh parliamentary elections Oleksandr Turchynov (Batkivshchina/People's Front) was speaker (as well as acting head of state until May). The new parliament initially elected Vasily Hroisman (BPP) as speaker, but his appointment as prime minster left the place vacant for his deputy, Andriy Parubiy (People's Front), who was also loyal to Poroshenko. Successive speakers have been able to influence agenda-setting and the outcomes of voting by selective application of the Reglament. This included acceptance of the practice of deputies' voting for each other (so-called piano-voting or knopkodavstvo (lit. button-pushing), sometimes for 6 or 7 colleagues) in violation of the Constitution, as well as

\footnotetext{
${ }^{13}$ Law of Ukraine 'pro Reglament Verkhovnoyi Rady Ukrainy', no.1861, $10^{\text {th }}$ February 2010. Available at www.rada.gov.ua, accessed $27^{\text {th }}$ July 2017.
} 
systematic manipulations such as reshuffling the agenda, frequently using the 'shortened procedure' meant for small amendments to examine new, sometimes major, legislation and putting bills to the vote multiple times. Thus, to a considerable extent, the speaker's power over the chamber was rooted in informal practices of selective application of rules and conscious rule violations.

In this patronal environment, the Rada as an institution was extremely porous to external stimuli, predominantly from the president, but also other national and regional patronal networks that shape parties' and deputies' interests. Interest in parliament as a deliberative, decision-making, communicative and symbolic organ was low and existed alongside longstanding cultural norms like deputies selling their votes or changing faction for money. This parliamentary culture, the broader patronal environment and shifting elite constellations form the political opportunity structure that shaped the meanings and prompted the adaptations of parliamentary protest in Ukraine.

Taken together the regime configuration, the composition of parliament and the allegiance of the speaker comprise the main features of the political opportunity structure for the conduct of parliamentary disruption, but the paper does not aim to establish a causal link between regime dynamics and levels of protest. For this, one would need reliable data on the frequency of protests over time which, as noted previously, are unavailable. Therefore, it will not be possible to conclude, for instance, that a single pyramid system leads to more disruption due to the increased exclusion of the opposition from decision making. However, four expectations about how the political opportunity structure can shape the prevalence of certain types of protest at certain times, and the adaptation and innovation in protest repertoires can be identified:

1. The exclusion of an elite group from access to the main patronal network (via exclusion from the government, parliamentary coalition or parliamentary leadership or marginalisation of the constitutional role of parliament) will increase contention in parliament, leading to more radical modes of disruption (e.g. sustained blocking of the work of parliament) and/or innovation in the protest repertoire, including attempts to delegitimate the executive.

2.The intensity and duration of disruption will be greater where all opposition factions work together. This is obvious, but crucially, the opposition will be more capable of collective action a) where the majority is narrow (because this generates opportunities to limit majority dominance through cooperation, plus the opposition is more confident to act due to the evidence of electoral support) and b) where the opposition is repressed (as this reduces the opportunities to use conventional parliamentary instruments and creates a sense of injustice and urgency). 
3. Attempts by the executive to consolidate a single pyramid of power will harden distinctions between majority and opposition and incentivise this opposition to engage in sustained campaigns of claim-making, public performances and repeated displays of public worthiness, unity and commitment (Tilly and Tarrow 2007, p.8). In other words, the parliamentary opposition mimic some characteristics of social movements as the repertoire of justifiable protest expands.

4. Extensive use of protest risks ritualisation and diminished effectiveness (Spary 2013, p. 410).

The paper will therefore draw on the ideas of contentious and patronal politics to help account for the use and transformation of the repertoire of parliamentary disruption during 2012-16. Furthermore, ideas of democracy inform our understanding of the meanings of various modes of protest. Disruptive protests reflect the patronal political system in which they are performed, straddling formal rules and informal practices, and are used by deputies to perform democratic parliamentary roles such as articulating claims to represent (which may be partisan or material, and may mask personalist lobbying). They also include the performance of claims to uphold or defend democratic institutions and procedures in Ukraine. Protests that make democratic claims can at certain times (i.e. during greater system closure) help maintain pluralism, but these also tend to promise direct or potential pay-offs for the politicians that perform them. How this plays out in practice is explained below.

\section{Performances and Repertoires}

Six basic modes of performing protest are identifiable, which together comprised the Verkhovna Rada's protest repertoires. These were: rostrum-blocking; withdrawal (walk-out/boycott); auditory disruption; visual disruption; somatic disruption and the spectacle. Performances were not exclusive, but could be combined to be mutually reinforcing. It was particularly common to join rostrum-blocking with visual or somatic disruption. Where three or more were conjoined together with elements of theatrical performance, these are classed as spectacles. During Yanukovych's presidency, the protest repertoire was predominantly employed by the opposition factions, and the change in the political opportunity structure generated by Tymoshenko's imprisonment prompted novel and more radical performances, particularly using visual, somatic protest and combining them into set-piece spectacles in Yanukovych's presence. After the 2012 elections, there was much greater coordination between the opposition "three" on organised protests on procedural and substantive issues. However, majority factions also occasionally used auditory disruption and session boycotts in attempts to undermine opposition claims, and used blocking to prevent disruption. During the 2014 interregnum, protest virtually disappeared as the ongoing national emergency had a pacifying effect and elites were reconfiguring. Under Poroshenko, from 2015 protest was no less frequent 
than under Yanukovych, but the repertoire changed: spectacles and regular auditory disruption disappeared and sustained rostrum blocking only re-emerged in summer 2016. Such protest was, however, much more marginal within and outside the Rada. In the main, protest became the regular recourse of two small opposition factions, changing its meaning and place in the political system. In more democratic circumstances, minor parties' disruptive protests were less justifiable and often associated with publicity-seeking. This suggests that the political opportunity structure, particularly regime type and parliamentary composition were crucial in shaping the meaning and significance of parliamentary protest as well as prompting its adaptation. Although modes were frequently combined, they will be analysed separately to consider variations in the types of claims made, motivation and political opportunity structure before finally turning to consider the broader significance of the Rada's protest repertoires.

\section{Rostrum-Blocking}

Rostrum-blocking was favoured because of its potential to physically prevent decisions being taken and sessions from being held. Sometimes as few as eight but as many as 200 deputies would physically block the rostrum for a few minutes, several days or (more rarely) several months. It is useful to distinguish between a) situational blocking and b) sustained blocking by the opposition, as sustained blocking is much more radical, and also c) preventative blocking used by the majority. Although precise data is unavailable, mapping of media reports and observations produces a clear periodisation in the use of blocking: Preventative blocking was used infrequently throughout; Situational blocking was common throughout 2012-16, except for the 2014 interregnum, when it was only used once; Sustained blocking was used extensively during 2012-February 2014, but then disappeared until April 2016. Changes in the political opportunity structure explain these patterns.

Situational blocking is defined as blocking for no more than one session day as a result of internal parliamentary procedural disputes. It was predominantly spontaneous as the principal means to protest the selective application as well as outright violation of the Reglament (and Constitution), which was endemic in the Rada. It used when the speaker committed or permitted procedural violations that were unfavourable to the opposition (e.g. excluded an agreed opposition item from the agenda; denied them the opportunity to speak). In other words, situational rostrum-blocking was a tool used mainly to remedy internal procedural conflicts. This was a low-cost protest - it required only a few deputies from one faction that offered a means for the opposition to seek redress for rule violation or make themselves heard when the majority disagreed with them. It was also low-cost because this form 
of transgressive parliamentary behaviour had a long lineage in independent Ukraine and was tolerated as normal (see Whitmore 2018).

So situational rostrum-blocking aimed to remedy a perceived injustice or to register the opposition's strong disagreement and sense that an injustice had occurred. For example, when the head of the Central Electoral Commission, Volodymyr Shapoval, was dismissed by parliament, the three opposition factions blocked the rostrum claiming that his removal was illegal due to various procedural irregularities. Opposition deputies also highlighted that replacing this official was undertaken by the majority to gain an advantage in the conduct of future elections. ${ }^{14}$ In this way, the opposition used blocking to articulate claims on the majority that related to notions of democracy in a particular and a general sense. Specifically drawing attention to procedural issues questioned the legitimacy of that decision, which like all parliament's decisions rests on the claim of legal rule conformity and the rule of law (that rules are constant and apply to all). As such the democratic nature of the decision was challenged. At a more general level, the opposition was performing a narrative of majority dominance and the threat that presented to Ukrainian democracy (in this case to free and fair elections). Disrupting the parliamentary session was thus justified by the claim to be upholding democracy. Therefore, the opposition were acting morally, in contrast to the majority. Such justification is a leitmotif of rostrum-blocking more broadly, as encapsulated by deputy Andriy Pyshnyi: 'If we can hinder the ... ruination of democracy by blocking, then this is very necessary'. ${ }^{15}$

However, moral claims sat alongside material interests, and were responses to changes in the political opportunity structure. Rostrum blocking has a long lineage in the Rada, first emerging in June $1990,{ }^{16}$ but after 2000 sustained rostrum-blocking became the mode of choice for parliamentary opposition parties who had lost influence in the government. Every rostrum-blocking over ten days in duration occurred following a change in government composition (OPORA 2013). Sustained rostrum-blocking was ultimately about who held the whip (and the buns). It was therefore planned, usually included large numbers of deputies and regularly was combined with other modes of disruption, particularly visual. That this form of protest became more common was in part due to the high stakes and heightened political conflict (Shukan 2013), particularly as the political system cycled between single

\footnotetext{
${ }^{14}$ Holos Ukrainy, $5^{\text {th }}$ July 2013.

${ }^{15}$ Interview, Kyiv, $11^{\text {th }}$ June 2013.

${ }^{16}$ Pravda Ukrainy, ${ }^{\text {th }}$ June 1990.
} 
and multi-pyramid forms. Therefore, it is predictable that opposition factions made extensive use of sustained blocking to resist Yanukovych's attempted authoritarian consolidation (see below), and that the factions that left the coalition in 2016 resurrected this method in the aftermath. For example, the Radical Party blocked the rostrum during summer 2016 demanding a parliamentary investigation into officials' (particularly the president's) offshore companies, although this issue had been voted on. In more democratic circumstances, such protest was harder to justify, and looked suspiciously like self-publicising. However, parliamentary sessions were conducted around the blocking, with bills presented and discussed from the floor. ${ }^{17}$ Sustained blocking, like short-term blocking, was often grounded in procedural claims - that the authorities were infringing the Reglament to gain an advantage in the broader political struggle. In this way, parliamentary procedures as a cornerstone of rule of law provided the basis for deputies to articulate claims about the anti-democratic and unfair behaviour of their counterparts in power. Yet appeals to procedural correctness tended to be only made about decisions that the opposition perceived as critical to the broader power struggle.

The case par excellence was piano-voting (the aforementioned practice of voting for one's colleagues), which was a long-bemoaned issue ${ }^{18}$ but became politically salient in the fight for power in 2013 due to the arithmetic of the newly elected parliament. There were other reasons why it became salient at this point (see below), but a key reason deputies were willing to pursue this claim so vigorously was that personal voting would deliver concrete gains to the opposition as the majority relied on many deputies who attended plenary sessions rarely and gave their voting card to colleagues to use. A successful campaign to uphold the Constitution (art.84 states that deputies must vote personally) and Reglament would deprive the majority of an assured majority, question the legitimacy of all decisions taken by that majority and allow the opposition to display moral rectitude.

Piano-voting was long-established in the Rada. The vast majority of deputies practiced it at one time or another. During the election campaign of 2012 however, piano-voting became a valance issue thanks to a sustained campaign by NGOs CHESNO and OPORA who persuaded deputies (principally from UDAR and Batkivshchina) to make campaign promises to vote personally. Once elected, these factions (later joined by Svoboda) demanded the implementation of a new voting system that would make piano-voting impossible. To this end, they began blocking the work of the Rada open-endedly round-the-clock, accompanied by strong visual protests (see below).

\footnotetext{
${ }^{17}$ Author's observations.

${ }^{18}$ Plenary observation, $7^{\text {th }}$ July 2000.
} 
The PRU threatened parliament's dissolution, constitutional changes ${ }^{19}$ and criminal cases for blocking. ${ }^{20}$ Finally, after 17 days a compromise was reached whereby the Reglament were amended to introduce sanctions for pianovoting. The parliament worked for one plenary day, during which time the majority could only muster 194 votes (of 226 needed) before being blocked again.

Deputies justified sustained rostrum-blocking as the only means available to them because the majority (and specifically the PRU) rode roughshod over all opposition initiatives and offered no opportunities for compromise or consensus ${ }^{21}$ even on very controversial social issues. In other words, it was seen as a last resort in extreme circumstances, a position shared by many experts and activists. ${ }^{22}$ The complete disruption of parliamentary decision-making was from this perspective a necessary part of the political process to resist Yanukovych's attempted authoritarian consolidation. It was the only means available to the opposition to remain visible in the public space and perform a resonant narrative about majority dominance through unconstitutional means, while establishing their own morality in upholding the constitution and their electoral promises. One deputy explained:

I promised my voters I would adhere to the Constitution, to the laws of Ukraine and do everything to uphold these laws. Therefore, if these laws are violated, we take the necessary action to correct this. ${ }^{23}$

Personal voting was thus seen as essential to uphold the constitution and the $1 \mathrm{w}^{24}$ particularly as the majority were illegally forcing through parliament harmful decisions for Ukrainian society, nationhood and statehood. ${ }^{25}$ Blocking was therefore morally justified to prevent such decisions, and the opposition were, in the face of physical

${ }^{19}$ Holos Ukrainy, $4^{\text {th }}$ April 2013.

${ }^{20}$ Segodnya, $19^{\text {th }}$ February 2013.

${ }^{21}$ Interviews in Kyiv with Leonid Yemets, $23^{\text {rd }}$ May 2013; Rostyslav Pavlenko, $4^{\text {th }}$ June 2013; Volodymyr

Yavorivskyi, $5^{\text {th }}$ June 2013; Andriy Parubiy, $3^{\text {rd }}$ June 2013; Andriy Pyshnyi, 11 ${ }^{\text {th }}$ June 2013.

${ }^{22}$ Interviews in Kyiv with Hanna Hopko, $25^{\text {th }}$ June 2013; Ihor Zhdanov, $26^{\text {th }}$ June 2013; Ihor Koliushko, 21st June 2013; Ihor Kohut', 22 ${ }^{\text {nd }}$ June 2013; Eleanor Valentine, 23 ${ }^{\text {rd }}$ July 2012.

${ }^{23}$ Interview in Kyiv with Leonid Yemets, 23 ${ }^{\text {rd }}$ May 2013.

${ }^{24}$ E.g. Interviews in Kyiv with Ihor Shvaika, $3^{\text {rd }}$ June 2013; Rostyslav Pavlenko, $4^{\text {th }}$ June 2013; Andriy Parubiy, $3^{\text {rd }}$ June 2013.

${ }^{25}$ Interviews in Kyiv with Deputy D, 24 ${ }^{\text {th }}$ May 2013; Volodymyr Yavorivskyi, $5^{\text {th }}$ June 2013; Andriy Pyshnyi, $11^{\text {th }}$ June 2013; plus Klychko, Zerkalo Nedeli $14^{\text {th }}$ February 2013. 
and judicial threats, somatically defending Ukrainian democracy and statehood. At the same time, highlighting piano-voting permitted the opposition to raise questions in the public consciousness about the legitimacy of all decisions taken since Yanukovych's election ${ }^{26}$ and thus the legitimacy of the government and the regime more generally, while offering the potential of the opposition being able to restrain majority actions in the future. Finally, as Gandrud (2016) anticipates, the sense that the 2012 election result was disproportionately favourable to the PRU and that the opposition was actually supported by a majority of the population also fed into deputies' justification for their actions. ${ }^{27}$ Batkivshchina and UDAR could expect this action to be beneficial for their ratings, as they were delivering on their election promises and polls showed the protest had substantial popular support. ${ }^{28}$ In this way, rostrum-blocking was substituted for more conventional, rule-bound parliamentary actions as a way for the opposition to perform its representative roles, to advance a claim originating in society and to perform their superior morality and democratic credibility. The 'Vote Personally' campaign was, in summer 2013, widely cited by deputies and experts as an example of the effectiveness of rostrum-blocking to enact political change. ${ }^{29}$ However, its success was short-lived as incidences grew after 2016. Predictably in a patronal system, many of the same politicians would later tolerate piano-voting once the boot was on the other foot.

Other claims advanced by sustained rostrum-blocking were on substantive rather than procedural issues, such as to demand an end to domestic gas price rises $(2010,2016)$, to prevent the adoption of the controversial language law (2012), to protest Tymoshenko's prison treatment (2013), to demand an investigation into President Poroshenko's off-shore accounts (2016) and to advance the evolving demands of the Maidan during the winter of

\footnotetext{
${ }^{26}$ E.g. Yatseniuk in Zerkalo Nedeli, $6^{\text {th }}$ February 2013.

${ }^{27}$ Interviews in Kyiv with Deputy D, 24 $4^{\text {th }}$ May 2013; Leonid Yemets, $23^{\text {rd }}$ May 2013; Rostyslav Pavlenko, $4^{\text {th }}$ June 2013; Andriy Parubiy, $3^{\text {rd }}$ June 2013; Andriy Pyshnyi, 11 $1^{\text {th }}$ June 2013.

${ }^{28}$ According to survey data, $55.5 \%$ Ukrainians supported this protest, rising to over $75 \%$ among opposition voters. Razumkov Centre (2013), Dumka hromadian Ukrainy pro sytuatsiiu v kraini, otsinky diialnosti vlady ta opozitsii, elektoral'ni orientatsii (copy provided by Yuriy Yakymenko).
}

${ }^{29}$ Interviews in Kyiv with Leonid Yemets, $23^{\text {rd }}$ May 2013; Ihor Shvaika, $3^{\text {rd }}$ June 2013; Rostyslav Pavlenko, $4^{\text {th }}$ June 2013; Andriy Parubiy, $3^{\text {rd }}$ June 2013; Deputy A, $5^{\text {th }}$ June 2013; Deputy B, $11^{\text {th }}$ June 2013; Sergiy Taran', $24^{\text {th }}$ June 2013; Hanna Hopko, $25^{\text {th }}$ June 2013. Some deputies however argued that rostrum blocking was internally focused on parliament and elites in defence of the opposition's rights, and could be damaging to a party's rating (e.g. Andriy Pyshnyi, $11^{\text {th }}$ June 2013). 
2013-14. These did not produce concrete results but that was unlikely to have been a goal. Rather blocking permitted performances of opposition to majority dominance and perceived injustice. This gained more media attention than parliamentary speeches or voting against and permitted parties to demonstrate their activeness to their electorates. ${ }^{30}$ Blocking that took place on issues fundamentally linked to the wider political struggle between the government and opposition was often focused on the political elite, but on substantive contentious issues with wide social resonance, the target audience was voters, via media coverage

Preventative blocking is noted here not because it was protest or disruptive, but rather it was the employment of the protest repertoire to prevent or undermine protest, a motif worth consideration in Ukrainian parliamentary practice. It was infrequent, but was employed by pro-presidential factions to regain control of the parliament where sustained opposition blocking was ongoing or threatened. For example, BPP blocked the rostrum to prevent the Radical Party disrupting the appointment of a new Procurator General on $12^{\text {th }}$ May 2016. This action was therefore directed primarily at the opposition factions.

Although rostrum-blocking was pursued with democratic justification, such as upholding the constitution or Reglament, it is difficult to separate this from the seeking of specific strategic or tactical advantages in the ongoing political battle, as it was predominantly employed to secure/prevent certain changes to the rules of the game. In this way, it was primarily addressed to internal parliamentary forces or the executive, but it was also used to communicate with voters on core electoral issues, demonstrating parties' action on the national stage. This form of protest ultimately represents the breakdown of parliamentary deliberation and as such is difficult to reconcile with notions of claim-making and representation advanced by democratic theorists.

\section{Withdrawal: the Walk-Out and Boycott}

Walk-outs and boycotts have been coupled together for analytical purposes because of their similar meanings and effects. Both comprise powerful performative acts that question the legitimacy of the existing authorities and their effects are largely symbolic. During the 1990s, walk-outs and refusal to register or participate in voting were the most utilised form of parliamentary disruption (see Whitmore 2018), but during the $21^{\text {st }}$ century these were seldom used. Beetham (2013, p.16-20) reminds us how participating in performative acts like voting or listening to the president speak in parliament provide a stage for subordinate parts of the elite to publicly assent to the current power-holders' authority. Walk-outs and refusals to participate in voting can therefore be understood as

\footnotetext{
${ }^{30}$ Interviews in Kyiv with Andriy Parubiy, $3^{\text {rd }}$ June 2013; Olena Rybiy $20^{\text {th }}$ June 2016.
} 
performative withdrawals of consent. Opposition factions Batkivshchina and NUNS walked out of Yanukovych's inauguration (see 'Spectacle') and boycotted parliamentary sessions in September 2011 after the imprisonment of their leaders. In December 2012, the three opposition factions staged a walk-out to protest Yanukovch's decision to address the new parliament by video-link rather than in person. ${ }^{31}$ The opposition was seeking to undermine public rituals that reinforce and perpetuate existing power relations. When the president speaks at parliament, deputies attentively listening represents a public demonstration of their acceptance of the right of the incumbent to hold that post. Walking out at the start of the speech so that a virtual president addressed a half-empty chamber conveyed contrary messages: the president performed contempt for the new parliament and his unwillingness to risk his physical presence in the chamber while the opposition demonstrated their refusal to consent to power exercised in a remote, unaccountable manner. Walk-outs were not only organised by opposition factions. In 2013 the majority of PRU and communists also staged a walk-out to protest Svoboda bringing controversial nationalist symbols into the chamber. ${ }^{32}$ In 2016, BPP organised a walk-out during prime minister Yatseniuk's annual report, publicly turning their backs on 'their' prime minister. Walk-outs retained their power precisely because of the strong symbolic potential to challenge the legitimacy of others' actions.

Voting boycotts were also rarely used. Parliamentary voting can be understood as a ritual that has little effect on political outcomes as far as all key decisions are decided elsewhere in advance, but as an act it serves to mystify existing power relations - to show decisions are being taken publicly by elected representatives according to codified rules - and thus conveying that power is being exercised legitimately by existing power-holders (Kertzer 1988, p.48-50). Refusal to participate in voting could thus signify attempts to delegitimise the exercise of power. However, non-voting was a widespread Rada practice, rendering boycotts an invisible form of protest. ${ }^{33}$ Nevertheless, during 2015-16, the existence of a large but undisciplined majority created opportunities for small coalition factions to use boycotts to press for concessions. Most effectively, this was used by Samopomich during December 2015 to ensure repeat mayoral elections were scheduled in Kryvih Rih. Once the small factions left the coalition, such boycotts had little leverage and were again disused.

\footnotetext{
${ }^{31}$ Holos Ukrainy, 14 $4^{\text {th }}$ December 2012.

${ }^{32}$ Korrespondent, $11^{\text {th }}$ October 2013, http://korrespondent.net/ukraine/politics/1614008-rybak-svobodovcy-neimeli-prava-prinosit-v-radu-cherno-krasnyj-flag, accessed 19 $9^{\text {th }}$ December 2017.

${ }^{33}$ I am grateful to Olena Rybiy for this point (via email, $20^{\text {th }}$ December 2017).
} 


\section{Auditory Disruption}

Spontaneous audible reactions including shouting, clapping, singing the national anthem, banging on the deputies' desks were not uncommon in the Rada of the 1990s. Noise was not simply auxiliary to other forms of protest, it was a distinctive mode of protest used to register disapproval or approval, as in other national parliaments (including, famously, Westminster). It was rarely reported, except in the parliamentary stenogram where 'Noise in the hall' is regularly recorded from the 1990s. However, the style of audible disruption was abruptly adapted during the $7^{\text {th }}$ convocation (2012-14) to incorporate ritualised soccer-style chanting which, when accompanied by banging on the desks created a din powerful enough to overwhelm attempts to conduct parliamentary business. Therefore, during 2012-14 however, the repertoire of auditory disruption expanded in form and frequency.

There are two particularly notable chants from the period that were used repeatedly: 'Free Yulia' by the opposition, principally Batkivshchina, a chant that was used together with other forms of protest (see below) and “Oo-krai-yin-ska!” ('[Speak] Ukrainian!') by Svoboda. Previously, opposition factions used chanting or banging on the desks to perform their marginalisation and to attract attentive publics to decisions taken without their consent. Now the radical right-wing party Svoboda, who entered parliament in 2012, imported their repertoire of contention acquired from participating in street protests. From the outset, Svoboda made it their signature move to chant in unison "Ukrainian!" and whistle at anyone who spoke Russian during the parliamentary session, often accompanied by banging on the tables. Faced with such rebuke during his maiden speech as speaker, Volodymyr Rybak hastily switched to speaking Ukrainian mid-sentence, but other majority deputies (some of whom had been speaking Ukrainian in plenary sessions for years) confrontationally switched to Russian, utilising a different form of protest aiming to provoke their opponents (e.g. PRU faction leader Oleksandr Yefremov) ${ }^{34}$ The Communists began counter-chanting "Neo-fascists" during Svoboda deputies' speeches, which on at least one occasion erupted into a mass brawl, ${ }^{35}$ starkly illustrating the complete breakdown of norms of rational decision-making through careful deliberation idealised in much democratic thought.

However, if the adversaries weren't listening to each other making reasoned arguments or policy evaluations, communication was still taking place. Svoboda's chants at their political opponents were an act of non-deliberative

\footnotetext{
${ }^{34}$ See 5 Kanal broadcast, $19^{\text {th }}$ March 2013, available at https://www.youtube.com/watch?v=0iyieTCTWAk, accessed $9^{\text {th }}$ January 2018.

${ }^{35}$ Holos Ukrainy, $19^{\text {th }}$ March 2013.
} 
speech, not intended to reach understanding, but rather to rebuke (Greene 2013) and to claim their moral superiority in defending the constitution and the law. ${ }^{36}$ Legally, parliamentary sessions are conducted in the state language i.e. Ukrainian, but until 2012 there existed an informal agreement whereby a small minority of deputies, predominantly businessmen from the Donbas, used Russian. ${ }^{37}$ In 2012 this consensus broke down with the adoption of the controversial language law that granted certain privileges to Russian language and was adopted with flagrant procedural violations. Svoboda entered parliament in the aftermath and exploited the resentment this and the 2010 Kharkhiv Accords had engendered, enabling them to cast themselves as defenders of the Ukrainian nation resisting a regime working against its interests and drew on their extensive experience in social movements. The regular chanting was novel and telegenic, and played into preconceptions about the 'hooligan' nature of Svoboda ${ }^{38}$ while making the party highly visible on the national stage (mostly as a convenient bogeyman for the Yanukovych-friendly media to scare voters and distract them from economic issues) who were able to present their unity, commitment, ideological and stylistic distinctiveness in ritual battles with (mostly) the Communists and communicate this to their core electorate. ${ }^{39}$ The effectiveness of this is debateable as neither Svoboda or the Communists entered the next Rada and this mode of behaviour evoked condemnation as a provocative form of $\mathrm{PR},{ }^{40}$ In the less ideologically polarised Rada of 2014-16, chanting resumed its place among the Rada's repertoire of audible disruptions as a mode to react to dubious decisions. The Radical Party's chanting of 'Shame' during the appointment of Yuriy Lutsenko as General Prosecutor is a case in point. ${ }^{41}$ The political opportunity structure shaped the viability of chanting as a useful mode of disruption. During 2014-16, the opposition leaders were no longer subject to selective justice and the democratic legitimacy of the parliament and president was generally accepted, reducing the level of contention within parliament considerably.

\section{Visual Disruption}

\footnotetext{
${ }^{36}$ E.g. Tiahnybok in Holos Ukrainy, $17^{\text {th }}$ April 2013.

${ }^{37}$ Author's observations.

${ }^{38}$ E.g. PRU statement, Tyzhden.ua, $12^{\text {th }}$ December 2012, http://tyzhden.ua/News/67437, accessed $9^{\text {th }}$ January 2108.

${ }^{39}$ Interview in Kyiv with Yuriy Yakymenko, 20 $0^{\text {th }}$ June 2013; Ihor Zhdanov, $26^{\text {th }}$ June 2013.

${ }^{40}$ E.g. Interviews in Kyiv with Ihor Zhdanov, $26^{\text {th }}$ June 2013; Oleksandr Chernenko, $26^{\text {th }}$ June 2013.

${ }^{41}$ Author's observation, 21th May 2016.
} 
Plenary chambers, Parkinson (2012: 112) contends, are dignified spaces which send cues that 'this matters', as sites for broad contention and claim-making. If certain voices or perspectives are not heard in that dignified space, then they are seen not to matter, and have less impact on the political agenda or the outcome of political deliberation. In Ukraine's 'winner-takes-all' system, those without access to the executive (and consequently, the 'feeding trough') ruptured the dignified space of the plenary chamber with banners, flags, stickers, leaflets and other props drawn from the protest repertoires of social movements in attempts to become or remain visible and relevant in the political system. It is logical then that visual disruptions became especially pronounced, almost a permanent fixture, during Yanukovych's attempted authoritarian consolidation as these paralleled intensified street protests by the opposition parties, but also because it was a form of protest extremely difficult for state and 'loyal' media to conceal. ${ }^{42}$ Once the dignified space had been routinely politicised however, it proved impossible to put the genie back in the bottle so that during 2014-16, a banner on the rostrum or the speakers' dais remained a constant, contributing the negative perceptions of the Rada as undignified. ${ }^{43}$

Banners were the most commonly used form of visual disruption during 2012-16. Despite prohibition in the Reglament (art. 53.1-2), and provisions to force participants to withdraw from the chamber if supported by $1 / 3$ in the chamber, there was never any attempt to prevent this form of protest (unlike, say, rostrum-blocking and chanting which at least evoked threats). Banners were used by the opposition factions to make claims on the majority and the president, for example to remind them about the imprisonment of their leaders on Yanukovych's personal orders and to render these incarcerated politicians visible and present in the political system (see below), before voters (via the media), international dignitaries and observers,although other deputies saw such protests as exclusively publicity seeking. ${ }^{44}$ For the 'Vote Personally' protest by the three opposition factions, a wellcoordinated and through-going approach was taken. Banners hung in front and behind the speakers' dais, as well as on the rostrum and from the guests' balcony, making it impossible to conceal totally, and was combined with co-ordinated dress (see somatic protest) and stickers by their voting buttons asking deputies to only vote for themselves.

\footnotetext{
${ }^{42}$ Interview in Kyiv with Serhiy Taran', 24 ${ }^{\text {th }}$ June 2013.

${ }^{43}$ Focus groups conducted by the author, Kyiv, June 2016.

${ }^{44}$ E.g. Oles' Doniy, interview, Kyiv, $6^{\text {th }}$ June 2013.
} 
Strikingly, after the fall of Yanukovych the use of visual forms of protest became even more extensive, particularly the use of banners - behind the speaker's dais, hanging from the balconies, beneath the voting tableaus as well as becoming a permanent fixture on the rostrum. Most notably on $13^{\text {th }}$ January 2015 , Batkivshchina placed a banner 'Freedom to Nadiya Savchenko' on the podium. Savchenko was a helicopter navigator imprisoned in Russia who had been elected to the Rada in absentia on the Batkivshchina party list. Her imprisonment was widely perceived as unjust, so the banner's fixedness on the podium was designed as a constant reminder to the international community. It was only removed 16 months later by Savchenko herself, and she replaced it with another about the remaining Ukrainians in Russian custody. Around the podium though, the space was used for contention. During summer 2016 the Radical Party erected large banners to support their campaign for an investigation into Ukrainian officials with off-shore companies which hung for three months and were joined by Batkivshchina's protesting gas tariffs. Other banners accompanied these temporarily. Thus, the Rada chamber became a site for permanent visual campaigning, becoming so common as to be ritualised, losing much of its impact, yet simultaneously politicising the space and thus undercutting parliament's role as a public space for deliberation and representation of national issues.

Visual disruption was then exceptionally widespread during 2012-2016, often accompanied by somatic forms of protest. Under Yanukovych it was used by the opposition to maintain a presence in Ukraine's political process, but this had the unintended and lasting side-effect of politicising the parliamentary chamber and therefore reducing its symbolic power.

\section{Somatic Protest}

In legislative institutions, democratic roles of deliberation and claim-making are performed by embodied agents in ritualised public spaces, mediated by social and institutional factors that affect their reception (Rai 2012, Coole 2007). Here we might consider how far is the body instrumental - as a 'dramatic prosthesis' to discursive or protest performances and how far does it exert power in its own right (Coole 2007, p.416). Therefore, we need to attend to the ways in which the body is used in protest and how this shapes the meaning of that protest. The corporeal dimension of protest is, at one level, obvious in rostrum-blocking, walk-outs and spectacles where deputies literally use their bodies to disrupt parliamentary proceedings. Here we seek to explore the meaning and significance of the somatic performance in parliamentary protest, particularly the use of dress to transgress parliamentary norms and communicate messages; of gendered space and violence; and of notable politicised bodies in the Rada, particularly Yulia Tymoshenko, Nadia Savchenko and military veterans. Viktor Yanukovych 
was perhaps the most important body because he became the sustained target of somatic protests seeking to delegitimise as well as to make him feel physically insecure, and this is examined separately in the section on spectacle. The presence of foreign bodies in the parliament in the form of international delegations and diplomats for important and ceremonial occasions was also bent into the service of opposition protests.

In keeping with the notion of parliaments as dignified spaces, most have an established (if not necessarily codified) dress code, which in the West tends to be based on formal male business attire - suit and tie. The Reglament did not stipulate a dress code but a suit and tie were the norm, although a small minority of deputies wore their suit with a vyshyvanka (traditional Ukrainian embroidered shirt) from the perestroika period onwards and, until 2013, evoked little controversy. Vyshyvankas were accepted as formal attire, particularly for national holidays, and the wearing of national dress as an alternative to a business suit is common in other national parliaments (e.g. India's Lok Sabha). In Ukraine, the use of dress to overtly transgress parliamentary norms for political campaigns was an innovation that emerged as a direct response to the change in the political opportunity structure that occurred when Yulia Tymoshenko was arrested in August 2011, engendering increasing contention in society and in parliament, prompting innovations in the protest repertoire.

From 2011, specific state ceremonies and rituals were disrupted by the staging of spectacles (see below) by Tymoshenko's eponymous parliamentary factions. One novel component of this was the wearing of matching tshirts by over 100 Batkivshchina deputies with her photograph - on some occasions on a black background, others on white; sometimes behind bars. The printed slogans also varied over time, but 'Free Yulia' predominated on tshirts, banners and chants and became the name of the campaign. Batkivshchina (or their PR company) were mindful of the need for novelty and drama to maintain public attention and changed the message and imagery periodically. During the 'Vote Personally' campaign they chose first to wear blue and yellow ribbons, stylistically evocative of the 'Orange Revolution', then vyshyvankas, then white sweaters proclaiming 'Free Ukraine!' 45 The latter slogan not-so-subtly sought to build on the trope of symbolically equating Tymoshenko with Ukraine as a whole utilised during the Orange Revolution (Shekhovtsov 2013, p.739) by universalising her plight at Yanukovych's hands with the whole country's, and later, her freedom with Ukraine's European path. Dress was also used during the 'Free Yulia' spectacles as a means to dominate the space - at least the opposition half of the chamber - with a sea of photos of Yulia's face. This form of protest rendered it impossible to avoid her gaze or

\footnotetext{
${ }^{45}$ Holos Ukrainy, 20 $0^{\text {th }}$ February 2013.
} 
to hide her from public view (see 'Spectacle'). As her face looked out from $105^{46}$ (2011-12) and 99 (2012-14) deputies' chests, Tymoshenko became figuratively present in the parliamentary chamber at regular intervals and as such she remained a key player in Ukrainian politics, which was surely the opposite of Yanukovych's intensions when he imprisoned her. Imprisoned she was much more powerful than when in the Rada in flesh-and-blood and Louboutin's. She was a martyr, suffering for Ukraine and all the injustices currently being inflicted on her by the Yanukovych regime. The emotive power of inscribing heroic scripts about the bearers of Ukrainian nationhood onto an imprisoned female body was such that Batkivchshina repeated it in the 2014 election by placing Nadya Savchenko, the imprisoned helicopter navigator, at the top of their party list, ahead of Tymoshenko, now free and reconstituted in flesh and blood.

Batkivshchina used the body of Tymoshenko consciously in their campaign and the corporeal mode of protest gradually dominated as the campaign reached a crescendo during the autumn of 2013. As Tymoshenko's release was a key EU condition for signing the Association Agreement, the faction capitalised on the international attention, wearing the various campaign t-shirts in rotation. Finally, on $19^{\text {th }}$ November, debuting 'Freedom to Ukraine' sweaters, the faction invited Tymoshenko's daughter, Yevhenia, to parliament to watch the (failed) consideration of the bills to release her mother. Yevhenia Tymoshenko's presence was a way of embodying Yulia as well as humanising her as a mother with a suffering daughter. She was paraded in front of deputies who would be voting in the presence of the EU delegation to Ukraine and many foreign diplomats. The intended audience was elite, domestic and international, to bring additional pressure to bear on Yanukovych to tell his faction to vote to release her.

'Free Yulia' and 'Vote Personally' were largely cotemporaneous in the Rada and represented the first instances of advocacy NGO-style campaigning inside the plenary chamber. For 'Vote Personally' dress was initially used by UDAR, whose wearing of matching $\mathrm{t}$-shirts became a faction calling-card. They proclaimed the faction as a united team and a new type of politician. The latter was particularly important in a country where deputies were associated with ill-gotten wealth and self-serving corruption. Wearing red sweatshirts marked them out physically as distinct and suggested a more casual, thus egalitarian approach compared to elitist business suits. The three opposition factions used dress to mark out their distinctiveness as a team, with Batkivshchina choosing to associate voting personally with patriotism by wearing vyshyvankas, a conscious merging of Batkivshchina with the

\footnotetext{
${ }^{46}$ Size of faction $4^{\text {th }}$ April 2011.
} 
Ukrainian people, appealing to their core electorate. In contrast, for 'Vote Personally', Svoboda came to the chamber without jackets and ties. The message was clear: we are ready for action, including fighting if required. ${ }^{47}$

After Yanukovych's departure, Batkivshchina's wearing of identical t-shirts to highlight certain campaigns became one of their 'signature moves', but deliberate somatic protests in the Rada were infrequent. One instance was after months of rostrum blocking by the Radical Party and Batkivshchina demanding investigations into senior officials' off-shore companies and into gas pricing respectively. BPP and National Front used somatic protest to unblock parliament and regain the moral high ground. Deputies who were veterans from the war in Donbas, wearing military fatigues, preventatively blocked the rostrum and speaker's dais, calling blocking 'a criminal act' in a time of war. ${ }^{48}$ On one level, the veterans in their uniforms physically brought the ongoing conflict to centrestage in the Rada, reminding deputies before attentive publics of the existential threat facing the country, and reminding them also that some deputies has risked their lives to face this threat, while others were playing politics. On another level, these deputies' military experience was meant to remind opposition deputies that the coalition had the physical means to ensure the parliament could work unhindered. ${ }^{49}$ Thus, the Rada worked that day, enabled by moral grandstanding and physical threat.

Indeed, we need to acknowledge that physical threats formed part of the protest repertoire, and sometimes this escalated into brawling. Small scale fights predominantly erupted over procedure such as being illegitimately denied the right to speak. ${ }^{50}$ While larger scale brawls could also be over procedure (for example, the failure of the speaker to react to obvious piano-voting by the PRU on $6^{\text {th }}$ June 2013) they also occurred as an overspill from organised protests. ${ }^{51}$ Deputies were keen to stress that the opposition never initiated violence, they purely

\footnotetext{
${ }^{47}$ According to survey data, $74.4 \%$ of Batkivshchina voters and $85.4 \%$ of Svoboda voters supported the opposition parties' sustained rostrum blocking to ensure personal voting. Razumkov Centre (2013), Dumka hromadian Ukrainy pro sytuatsiiu v kraini, otsinky diialnosti vlady ta opozitsii, elektoral'ni orientatsii (copy provided by Yuriy Yakymenko).

${ }^{48}$ Author's observation, $8^{\text {th }}$ July 2016.

${ }^{49}$ Andriy Teteriuk, Holos Ukrainy, $8^{\text {th }}$ July 2016.

${ }^{50}$ E.g. between Nestor Shufrych (PRU) and Ivan Kyrylenko (Batkivshchina) on $11^{\text {th }}$ January 2013.

${ }^{51}$ Interviews in Kyiv with Deputy D, 24 $4^{\text {th }}$ June 2013; Rostyslav Pavlenko, $4^{\text {th }}$ June 2013.
} 
responded to provocation as a last resort in grave circumstances. ${ }^{52}$ Future speaker Andriy Parubiy explained, 'We are fighting not to protect ourselves, but to defend the Constitution. To stand by would be wrong. ${ }^{53}$ Andriy Pyshnyi echoed:

Ukrainian parliamentarism might not exist by 2015... [PRU deputies] are not thinking about the decisions that they are forced to pass by the presidential administration. [They] just press the button not understanding the consequences for the country. I'm ready to fight over this... This is a last resort, because beautiful words won't save the Constitution.

Thus, brawling became an extension of protest in the Rada that enabled the performance of masculinity - to defend visions of Ukraine and democracy, deputies were demonstrating willingness to risk bodily harm. Yanukovych's exit dramatically reduced violence in the chamber, but the effect was only temporary. Despite a huge turnover of personnel in the 2014 elections, small scale altercations and mass brawls remained frequent during 2015-16, even between coalition partners.

The exceptionally high levels of physical violence in the Ukrainian parliament (Gandrud 2016) wasn't novel, as periodic fist-fights occurred in the 1990s. However, mass brawls involving tens, and sometimes over a hundred deputies, were a relatively new phenomenon, no longer unusual after 2010, most infamously over the ratification of the Kharkhiv Accords (2010) and the language law (2012). Shukan (2013, p.439) attributes this change to heightened social conflict, 'depacification of relations among principal actors' and from 2006, she points to the recruitment of bodyguards and sportsmen as deputies to provide security to PRU deputies in the chamber. Such recruitment patterns, according to Aivazovska, emerged due to increased physical disruption in the Rada, particularly rostrum-blocking. Deputies' immunity meant that even Rada security guards could not enter the chamber, so the PRU required their own security who had immunity by virtue of being elected deputies ${ }^{54}$ For instance, a fight broke out at the start of the evening session on $12^{\text {th }}$ December 2012 as PRU deputies tried to unblock the rostrum from Batkvishchina and Svoboda deputies, but this followed an earlier fight that day when Batkivshchina deputies beat two tushki (lit. corpses - deputies elected on their list who immediately defected to

\footnotetext{
${ }^{52}$ Interviews in Kyiv with Leonid Yemets, $25^{\text {th }}$ May 2013; Andriy Parubiy, $3^{\text {rd }}$ June 2013; Rostyslav Pavlenko, $4^{\text {th }}$ June 2013.

${ }^{53}$ Interview, Kyiv, $3^{\text {rd }}$ June 2013.

${ }^{54}$ Interview, Kyiv, 27 $7^{\text {th }}$ June 2013.
} 
the majority). The spontaneous anger overflowing from an organised protest ensured wide media coverage and was understandable to (at least some) opposition voters who felt the tushki got their just desserts. ${ }^{55}$ From 2012 , the entry of Svoboda brought in radical right activists willing to use violence, which engendered competition among opposition factions to be the most radical, ${ }^{56}$ a factor that doubtlessly contributed to the physical escalation of conflict during that convocation.

Deputies' immunity and the prevalence of rostrum-blocking seems to have contributed to cumulative violence in the Rada over time because parties anticipated the need to forcibly unblock parliamentary work and recruited deputies for this task. Despite turnover in composition, non-deliberative (i.e. violent) responses in parliamentary debates were habituated, offering opportunities for performances of commitment and masculinity that could attract media and public attention. However, somatic protest encompassed literal and figurative forms. The body was purely instrumental in protests like rostrum-blocking and some violent spill-overs. However, during Yanukovych's presidency the soma took on a highly symbolic form to publicly question the president's legitimacy and rattle his self-confidence. Such aspects were prominent in deputies' use of spectacle.

\section{The Spectacle}

The spectacle brings together multiple modes of protest to embarrass, disturb and delegitmate the Yanukovych regime and decisions taken by it, utilising the repertoire of visual, auditory and somatic protest, often including an overtly theatrical element or props. For instance, during 'Vote Personally' a guillotine was placed on the speaker's dais chopping off a deputy's hand for piano-voting. ${ }^{57}$ Spectacles by definition were intended for a wide audience, including domestic and international actors, so they were often staged at state rituals where foreign diplomats and guests were present as well as being organised to attract maximum media coverage to speak to core and potential electorates. These protests focused on symbolic performances of simplified narratives that were intended to reinforce notions of good versus evil characters on the political stage and to embarrass the evil

\footnotetext{
${ }^{55}$ Interview in Kyiv with Ihor Zhdanov, $26^{\text {th }}$ June 2013.

${ }^{56}$ Batkivshchina formed a special group for fighting (Glavred, $6^{\text {th }}$ February 2013, http://glavred.info/politika/batkivschina-sozdala-specgruppu-dlya-drak-V-rade.html, accessed $9^{\text {th }}$ January 2018) and immediately after taking their oaths, both Svoboda and Batkivshchina announced their readiness for radical action (Holos Ukrainy, $13^{\text {th }}$ December 2012).

${ }^{57}$ Holos Ukrainy, $6^{\text {th }}$ February 2013.
} 
categories of embodied actors present in parliament as a means of disciplining them (Coole 2007, p.424). Parliamentary procedures and rituals serve to publicly demonstrate the consent of the representatives of different parts of the elite to the existing order and to the current power holders (Beetham 2013, pp.13-20, Kertzer 1988, Parkinson 2012). Logically then, disrupting parliament's procedures and rituals provides an opportunity for sections of the elite, or individuals, to seek to delegitimise existing authority through performative withdrawals of consent. This mode of disruption first emerged in 2002, when the sacking of the head of the National Bank and an attempted rotation of committee chairs led part of the opposition to expand rostrum blocking in form to encompass full-blown political spectacle staged with multi-facetted protests with visual, auditory and somatic aspects. This drew directly on the 'theatre of opposition' methods developed by the Povstan' Ukraino! social movement led by Tymoshenko and other opposition leaders (Wilson 2005, p.60). Until 2011, this mode was rarely employed, but for the 'Free Yulia' campaign, the spectacle was the parliamentary centrepiece and built on methods Tymoshenko was subjected to by the PRU while Prime Minister 2007-09 (Shukan 2013, p.451). Indeed, experts argued that the change in the political opportunity structure signified by Tymoshenko's imprisonment prompted and necessitated this spectacular type of protest, ${ }^{58}$ although this was accompanied by the recognition that such protests were ultimately damaging to democratic political communication and the dignity of parliament. ${ }^{59}$

From the beginning, the opposition refused to accept the legitimacy of Yanukovych's election: Tymoshenko challenged its legality in court and the opposition boycotted his inauguration. However, once the two leaders of the opposition were imprisoned, the opposition began to use the highly public state rituals in the parliament that required the president's participation to keep their imprisonment on the national and international agenda and to symbolically challenge Yanukovych's legitimacy to rule. These rituals included the official openings of parliamentary sessions, the ceremony to mark the $20^{\text {th }}$ anniversary of independence and the appointment of judges. The opposition staged spectacles designed to have maximum impact, with large public protests outside the parliament building and inside the chamber large banners with the photographs of the imprisoned leaders and slogans 'No political repression' and 'Free Yulia' were laid over 6-7 rows of deputies' seats. This meant that 2540 deputies could gather around each banner (after Lutsenko's release, just the 'Free Yulia' one was used) and lift it up and down rhythmically in the manner of sports' teams before the start of the match pugilism, while

\footnotetext{
${ }^{58}$ Interviews in Kyiv with Serhiy Taran', 24 $4^{\text {th }}$ June 2013; Ihor Zhdanov, $26^{\text {th }}$ June 2013; Olga Aivazovska, 27 th $^{\text {th }}$ June 2013.

${ }^{59}$ Interviews in Kyiv with Olga Aivazovska, 27 June 2013; Olena Rybyi, 20 ${ }^{\text {th }}$ June 2016.
} 
chanting 'Bandits out!', 'Shame' or 'Free Yulia' over and over to drown out the formal proceedings in the chamber. Deputies also dressed in matching attire, serving to reinforce the notion of them as a united team facing down their opponents.

The zenith of the opposition's success was on $7^{\text {th }}$ February 2012 when the president came for the opening of parliament and was forced to stand at the podium, waiting to make his speech, for five minutes of opposition chanting 'Free Yulia' in the presence of the government and foreign diplomats. He eventually quit the chamber, leaving the official parliamentary newspaper to print the speech as if it had been delivered normally. ${ }^{60}$ These humiliating experiences during 2011-12 Rada led Yanukovych to avoid being physically present there wherever possible, delivering his speeches via video to the opening of the $7^{\text {th }}(2012-14)$ convocation and in written form on $6^{\text {th }}$ June 2013. However, the appointment of judges compelled Yanukovych to make his first visit to the new Rada on $15^{\text {th }}$ May 2013. The opposition's chanting, visual and somatic protest meant that the president's visit lasted a mere 7 minutes. ${ }^{61}$ By refusing to express tacit consent to Yanukovych's exercise of presidential power and, by going further, to disrupt such exercise in front of national and international audiences, the opposition symbolically challenged the legitimacy of not only his decisions, but more profoundly, his legitimacy to rule. Given the political communication between the branches of power was already extremely poor, ${ }^{62}$ the opposition had nothing to lose by such spectacles. Rather they could help to generate a sense of momentum and purpose in protesting against Yanukovych outside parliament and, as Kertzer (1988, p.183) indicates, keep alive a vision of an alternative political reality in the face of repression. Such spectacles performed defiance and fearlessness and could be used to mobilise public support for the opposition ${ }^{63}$ and to unite the disparate parts of the opposition against a common enemy.

\footnotetext{
${ }^{60}$ Holos Ukrainy, $8^{\text {th }}$ February 2012.

${ }^{61}$ See Kanal 5's report available at https://www.youtube.com/watch?v=y5XO7 LHrdk, accessed 25 ${ }^{\text {th }}$ July 2017.

${ }^{62}$ Olga Aivazovska, interview, Kyiv, $27^{\text {th }}$ June 2013.

${ }^{63}$ In focus groups in Kyiv, citizens often saw such spectacles as attention-seeking PR, but opposition supporters reacted differently. One participant explained: 'It doesn't matter who [the leader] is. It is their leader, they are defending their interests. It is a bold sign of democracy at that time.'. Focus group at SME, Kyiv, $24^{\text {th }}$ June
} 2016. 
After 2014 spectacles were no longer necessary or justifiable in new political circumstances, and this form of protest was not used. The nearest example is the chanting of 'Shame!' by the Radical Party during Poroshenko's speech to introduce Lutsenko's controversial candidacy for Procurator General in May 2015. This protest consciously echoed the 'Free Yulia' spectacles, seeking to insinuate comparisons between Poroshenko and Yanukovych as the manner of the appointment was reminiscent of Yanukovych's style in terms of regard for procedure. ${ }^{64}$ As we've established, such an attitude to procedure prompted much protest in the Rada, and the Reglament provided little restraint to deputies' protests.

\section{Sanctions}

So far, sanctions for deputies' protests have barely been mentioned. This is not an oversight, but a reflection of their place in constraining and channelling parliamentary disruption in Ukraine. There existed, in the Reglament, prohibition of visual and auditory disruption as well as of 'abuse' (art.52) and established procedures for the imposition of sanctions. A vote by 150 of deputies could 'oblige' the deputy to leave the session (art. 53) or the speaker could charge the relevant standing committee - the Reglament committee ${ }^{65}$ - to examine the issue, followed by a parliamentary majority vote (226 votes) to deprive a deputy of the right to participate in plenary sessions for up to five days and the publication of their name in Holos Ukrainy (art.51.5). If a session is disrupted due to violations of the Reglament, then two factions can request a break (9.51.7). In November 2012 amendments were made prohibiting blocking the rostrum or the speaker's work, although no sanctions were stipulated (art.47.4). ${ }^{66}$ However, it was notable that these sanctions were barely, if ever, applied. ${ }^{67}$

${ }^{64}$ See Ukrains 'ka Pravda, $12^{\text {th }}$ May 2016, http://www.pravda.com.ua/news/2016/05/12/7108245/, accessed $12^{\text {th }}$ May 2016.

${ }^{65}$ The official name is the committee 'on Reglament and organisational work of the Rada'

${ }^{66}$ Law of Ukraine 'Pro vnesennia zmin do Reglamentu Verkhovnoho Rady Ukrainy' no.5520-IV, 6.12.12.

${ }^{67}$ Author's observations; interviews in Kyiv, including Eleanor Valentine and Edward Rakhimkulov, $23^{\text {rd }}$ July 2012; Ihor Koliushko, $21^{\text {st }}$ June 2013; Ihor Kohut', 22 ${ }^{\text {nd }}$ June 2013; Oleksandr Barabash, 22 ${ }^{\text {nd }}$ June 2013; deputies Rostyslav Pavlenko, $4^{\text {th }}$ June 2013; Volodymyr Yavorivskiy, $5^{\text {th }}$ June 2013; Andriy Pyshnyi, $11^{\text {th }}$ June 2013. 
Why? Firstly, deputies had immunity from detention, arrest and prosecution that could only be lifted by a majority vote $\left(226\right.$ votes) ${ }^{68}$ This meant inter alia that no-one could prevent a deputy entering or remove them from a parliamentary session, ${ }^{69}$ making implementation of the main sanction unenforceable. In the exceptional cases where a criminal case was initiated, it never reached court because of deputies' immunity. ${ }^{70}$ Therefore, provisions instituted to protect opposition deputies from encroachments by the state during the period of democratisation effectively made deputies untouchable, a factor that doubtlessly contributed to the prevalence and gradual escalation over time of transgressive protest in the Rada. Secondly, the mass nature of protests made the application of sanctions politically sensitive. As protests tended to be organised and conducted by whole factions or by the entire opposition, rather than by individual parliamentarians as tends to prevail elsewhere, it would be necessary to sanction large groups of deputies, potentially over 150 of them. ${ }^{71}$ Trying to exclude most of the opposition from parliament would significantly escalate the level of political conflict. Instead, the speaker responded with verbal appeals to order and rebukes, while the majority made various threats (see above). Concomitantly, the absence of a Leviathan to enforce rule adherence over the prevailing Hobbesian state-of-nature was recognised by deputies and experts. ${ }^{72}$ As noted previously, the speaker was a figure of the majority and was therefore unable to play the role of a neutral arbiter. The Reglament committee was also dominated by the majority, who used it as a partisan instrument and blocked its work where advantageous. ${ }^{73}$ The threshold for imposing sanctions was, in Ukrainian circumstances, prohibitive as 226 votes was difficult to achieve due to the

\footnotetext{
${ }^{68}$ Law of Ukraine 'Pro status narodnoho deputata Ukrainy', 2790-XII, 17.11.92.

${ }^{69}$ Interviews in Kyiv with Leonid Yemets, $23^{\text {rd }}$ May 2013; Andriy Parubiy, $3^{\text {rd }}$ June 2013 ; Serhiy Taran', 24 ${ }^{\text {th }}$ June 2013; Brian Mefford, $21^{\text {st }}$ June 2016.
}

${ }^{70}$ Andriy Parubiy reported that a case was opened against him for obstructing the work of parliament. Interview, Kyiv, $3^{\text {rd }}$ June 2013.

${ }^{71}$ Interviews in Kyiv with Oleksandr Chernenko, $26^{\text {th }}$ June 2013; Volodymyr Yavorivskyi, $5^{\text {th }}$ June 2013; Yuriy Yakymenko $20^{\text {th }}$ June 2013.

${ }^{72}$ Interviews in Kyiv with Deputy D (24 ${ }^{\text {th }}$ May 2013), Ihor Kohut, $22^{\text {nd }}$ June 2013, Olga Aivazovska, 27 th $^{\text {June }}$ 2013.

${ }^{73}$ Interviews in Kyiv with Andriy Pyshnyi, $11^{\text {th }}$ June 2013, Oleksandr Barabash, $22^{\text {nd }}$ June 2013, Yuriy Yakymenko 20 $0^{\text {th }}$ June 2013; Olga Aivazovska, $27^{\text {th }}$ June 2013. 
lack of solid majorities ${ }^{74}$ Furthermore, successive majorities were unwilling to apply sanctions due to an informal norm - the temporarily powerful do not impose sanctions on the temporarily weak over procedural violations including disruptions because everyone violates the Reglament and benefits from this arrangement over the longer game..$^{75}$ Therefore, the temporarily powerful risk opening Pandora's Box by utilising sanctions today that could be used against them tomorrow. ${ }^{76}$ Consequently, the deputy head of the Reglament committee reported in June 2013, following the most intense period of disruption during January-May 2013, where the Rada had been able to convene only seven of 32 scheduled plenary days, that the committee hadn't examined a single case of violations of the Reglament during plenary sessions. ${ }^{77}$

\section{Conclusions}

So, what has a broadly conceived, historically grounded approach to protest in the Rada added to our understanding of parliamentary politics in Ukraine? This study builds on Shukan's (2013) findings, but offers important refinements. While agreeing that violent disruption is linked to increased social and political contention and the sociological composition of parliament, examining a broader range of protest behaviour has facilitated the identification of six distinct modes of protest. Together they comprised a repertoire that was ulitised and adapted in response to changes in the political opportunity structure. The study enabled the interpretation of the contingent meanings of protest, including deputies' motivations for their conduct, as well as the elaboration of their relationship to the ideas and practice of democracy.

Innovations in the protest repertoire stemmed from changes in the political opportunity structure. The patronal nature of Ukraine's political system with a formally divided executive produced a cycling between more authoritarian and democratic (or, rather, pluralist (Way 2015)) formats, without fundamentally altering the 'winner-takes-all' logic of the system. Therefore, when one set of elites was denied access to the main patronal networks (by being excluded from the government, the parliamentary coalition or parliamentary leadership) this

\footnotetext{
${ }^{74}$ Interviews in Kyiv with Ihor Kohut, $22^{\text {nd }}$ June 2013, Rostyslav Pavlenko, $4^{\text {th }}$ June 2013, Oleksandr Barabash $22^{\text {nd }}$ June 2013.

${ }^{75}$ Interviews with Eleanor Valentine and Edward Rakhimkulov, 23 ${ }^{\text {rd }}$ July 2012. Also Whitmore 2004, p.178-9.

${ }^{76}$ Interviews, Kyiv, with Rostyslav Pavlenko, $4^{\text {th }}$ June 2013, Andriy Parubiy, $3^{\text {rd }}$ June 2013, Ihor Zhdanov, $26^{\text {th }}$ June 2013.

${ }^{77}$ Interview in Kyiv with Andriy Pyshnyi, $11^{\text {th }}$ June 2013.
} 
comprised part of a wider attempt to build a single pyramid of power and, consequently, caused an intensification of political contention that manifested itself in adaptations and extensions of parliamentary protest. Parliament was the site where the now oppositional elites maintained representation, visibility and the potential to influence decision shaping the future formal rules of the game, despite minority status, by a) preventing decisions being taken (this accounts for much sustained rostrum-blocking) and/or b) symbolic protests that made moral claims on the chief patron about the illegality of his actions before their electorate (this accounts for the adaptation of the spectacle at public state rituals involving the president 2011-13). Exclusion from the main patronal networks pushed the opposition to incorporate certain attributes of social movements into their protest repertoire. ${ }^{78}$ These were most marked during an attempt to consolidate a single pyramid of power and included sustained campaigns of claim-making (e.g. 'Free Yulia', 'Vote Personally'), an array of public performances (wide and innovative use of the protest repertoire), repeated displays of public worthiness, unity and commitment (moral claims, use of dress, soma, chanting, extended duration of protests). Formal institutional channels like parliament offered the opposition only limited opportunities for influence, and none on totemic issues like the 2012 language law. ${ }^{79}$ Therefore, deputies perceived their only option was resistance and disruption.

If innovation of protest repertoires can be attributed to changes in the political opportunity structure, what does parliamentary disruption tell us about the nature of Ukraine's political system? Can such protests contribute to democratic practice in Ukraine or are they better understood as indicative of wider system dysfunction? Protest in the Rada has a duality consistent with the nature of patronal regimes. On one hand, disruptive performances provided opposition factions with opportunities to perform some of parliament's democratic functions where these were informally limited, and to prevent their total marginalisation during moves towards a single pyramid system. Taken together, the protest repertoire permitted claims to penetrate the official media and reach wide audiences. It articulated claims grounded in democratic norms and resisted attempts to limit pluralism, highlighting majority

\footnotetext{
${ }^{78}$ Consistent with this argument, although not covered in this paper, the PRU made extensive use of such protests when out of power during 2005-06 and 2008-09. See Shukan (2013).

${ }^{79}$ Volodymyr Yavorivskyi, head of the profile committee, noted that of over 1000 amendments proposed, none were incorporated, and flagrant procedural violations were needed to adopt this law. Interview, Kyiv, $5^{\text {th }}$ June
} 2013. 
constitutional, legal and procedural violations and attempts to further close the system. However, the effectiveness and justifiability of protests was reduced in more pluralist conditions.

Extensive use of protest had deleterious effects on the Rada's performance of its democratic functions. In the case of visual disruptions, the effects were diffuse: they undermined the dignity of parliament and politicised a space for the representation and deliberation of issues of national significance. Similarly, spectacles were deeply divisive ${ }^{80}$ and blurred the lines between the legislature and a social movement, law-makers and the mob. Rostrumblocking might be regarded as the ultimate breakdown in deliberative norms in a national parliament, were it not for the pervasive violence. Moreover, during 2015-16, protests were increasingly ritualised, marginal and associated with self-publicity, although further research is needed to explore how citizens perceived such performances. To a large extent, the ambiguity of protest reflects the hybrid political system, where the democratic form of the national parliament cannot be realised de facto because the underlying patronal relations generate incentives for presidents to accumulate power formally and informally, to marginalise and control the Rada and for deputies to be executive clients focused on material gains. Such a dynamic supports Way's (2015) contention that in competitive authoritarian regimes the sources of pluralism also foster dysfunction and corruption. Protest performances, while articulating claims to uphold democracy that are politically resonant and contribute to the maintenance of pluralism in Ukraine during attempted authoritarian consolidation, simultaneously are parainstitutional instruments in the ongoing power struggle engendered by a patronal system where formal institutions and norms weakly constrain actors.

\section{References}

Beetham, D. (2013), The Legitimation of Power (London: Palgrave).

Chaisty, P. and Chernykh, S. (2015), 'Coalitional presidentialism and legislative control in post-Soviet Ukraine', Post-Soviet Affairs, 31, 3, 177-200.

Coole, D. (2007), 'Experiencing Discourse: Corporeal Communicators and the Embodiment of Power', British Journal of Politics and International Relations, 9, 413-433

\footnotetext{
${ }^{80}$ Evidence of focus groups in Kyiv, June 2016.
} 
D’Anieri, P. (2007), Understanding Ukrainian Politics: Power, Politics and Institutional Design (Armonk: M.E. Sharpe)

Gandrud, C. (2016), 'Two sword lengths apart: Credible commitment problems and physical violence in democratic national legislatures', Journal of Peace Research, 53(1), 130-145

Green, J.E. (2013), ‘Analysing legislative performance: a plebeian perspective’, Democratization, 20(3), 417437.

Hale, H. (2015), Patronal Politics: Eurasian Regime Dynamics in Comparative Perspective (Cambridge and New York, Cambridge University Press).

Herron, E. (2002), 'Causes and consequences of fluid faction membership in Ukraine', Europe-Asia Studies, 54(4), 625-639.

Johnson, R (2013), 'Disrupting the South African parliament: performing opposition 1994-2010', Democratization, 20(3), 478-500.

Kertzer, D. (1988), Ritual, Politics and Power (New Haven and London: Yale University Press).

Khmelko, I. and Beers, D. (2011), 'Legislative Oversight in the Ukrainian Rada: assessing the effectiveness of committees', Journal of Legislative Studies, 17(4), 501-524.

Kudelia, S. (2014), 'The House that Yanukovych Built', Journal of Democracy, 25(3), 19-34.

Levitsky, S. and Way, L. (2010), Competitive Authoritarianism: Hybrid Regimes After the Cold War, (Cambridge: Cambridge University Press).

Matsiyevsky, Y.(2017), 'Old Habits Die Hard in Ukraine’, PONARS Policy memo No.473, http://www.ponarseurasia.org/memo/old-political-habits-die-hard-ukraine, accessed $1^{\text {st }}$ June 2018.

Matsiyevsky, Yu. (2018), 'V lovushke gibridnosti: politicheskii rezhim v Ukraine posle revolyutsii 2014 goda' Polis. Political Studies, 1, 96-115.Matuszak, S. (2012), The Oligarchic Democracy: The Influence of Business Groups on Ukrainian Politics, OSW Studies No.42, available at http://www.osw.waw.pl/sites/default/files/prace 42 en.pdf, accessed $1^{\text {st }}$ June 2013. 
OPORA (2013), 'Ukrainian practices of blocking the parliament', $25^{\text {th }}$ February, available at https://oporaua.org/en/parliament/34214-7346-1446979951-ukrajinski-praktyky-blokuvannja-parlamentu, accessed $27^{\text {th }}$ June 2013

Ostapchuk, D. (2016), 'The Power series, season 4: Verkhovna Rada under the microscope-2', Vox Ukraine, $16^{\text {th }}$ October, available at http://voxukraine.org/longreads/coalition/article-en.html, accessed $17^{\text {th }}$ October 2016.

Packenham, R. (1990), 'Legislatures and Political Development' in Norton, P. (1990), Legislatures (Oxford: OUP), 97-124.

Parkinson, J. (2012), Democracy and Public Space: The Physical Sites of Democratic Performance (Oxford: OUP).

Pleines, H. (2016), ‘Oligarchs and Politics in Ukraine', Demokratizatsiya, 24(1), 1-5-127.

Rai, S. (2012), Political Performance: Reading Parliamentary Politics, Warwick Performance and Politics Network Working Paper, No.1, The University of Warwick

Rai, S. (2013), 'Disruptive Democracy: analysing legislative protest', Democratization, 20(3), 385-391.

Rybiy, O. (2013), 'Party system institutionalisation in Ukraine', Demokratizatsiya, 21(3), 401-23.

Shekhovtsov, A. (2011), 'The Creeping Resurgence of the Ukrainian Radical Right? The Case of the Freedom Party', Europe-Asia Studies, (63)2, 203-228.

Shekhovtsov, A. (2013), 'The 'Orange Revolution' and the 'Sacred' Birth of a Modern Ukrainian Nation', Nationalities Papers

Shukan, I. (2013), 'Intentional disruptions and violence in Ukraine's Supreme Rada: political competition, order, and disorder in a post-Soviet chamber, 2006-2012', Post-Soviet Affairs, 29(5), 439-456.

Spary, C. (2013), 'Legislative protest as disruptive democratic practice', Democratization, 20(3), 392-416.

Tarrow, S. (1998), Power in Movement: Social Movements and Contentious Politics, Cambridge: Cambridge University Press.

Tilly, C. (2008), Contentious Performances (Cambridge: CUP). 
Tilly, C. and Tarrow, S. (2007), Contentious Politics (Boulder and London: Paradigm).

Way, L. (2015), Pluralism by Default: Weak Autocrats and the Rise of Competitive Politics (Baltimore: John Hopkins University Press)

Whitmore, S. (2004), State-Building in Ukraine: The Ukrainian Parliament, 1990-2003 (London: RoutledgeCurzon)

Whitmore, S. (2018), 'The Origins of Protest and Disruption in the Ukrainian Parliament', Neprikosnovennyi Zapas (forthcoming).

Wilson, A. (2005), Ukraine's Orange Revolution (New Haven, CT \& London, Yale University Press).

Wilson, A. (2016), Survival of the Richest: How Oligarchs Block Reform in Ukraine, European Council on Foreign Relations Policy Brief, $14^{\text {th }}$ April, available at $\underline{\text { http://www.ecfr.eu/page/- }}$ /ECFR 160 SURVIVAL_OF THE_RICHEST-_HOW_OLIGARC1_BLOCK_REFORM_IN_UKRAINE.pdf, accessed $1^{\text {st }}$ May 2016.Zimmer, K. (2006), 'Formal Institutions and Informal Politics in Ukraine', in Meyer, G. (ed)(2006), Formal Institutions and Informal politics in Central and Eastern Europe (Leverkusen Upladen, Barbara Budrich), 274-313. 